\title{
Screening of yeast for alcoholic fermentation of no sugar-added tomato concentrate
}

\author{
Dong-Hwan Kim ${ }^{1}$, Jae-Nam Moon ${ }^{2}$, Seul Lee ${ }^{2}$, Soo-Won Lee ${ }^{1}$, \\ Hey-Kyung Moon ${ }^{3}$, Gwi-Young Kim ${ }^{1 *}$ \\ ${ }^{1}$ Department of Food and Food Science and Technology, Kyungpook National University, Sangju 37224, Korea \\ ${ }^{2}$ School of Food Science and Biotechnology, Korea Food Research Institute, Kyungpook National University, Daegu 41566, Korea \\ ${ }^{3}$ Center for Scientific Instruments, Kyungpook National University, Sangju 37224, Korea
}

\section{토마토 농축액을 이용한 무가당 알코올 발효를 위한 효모의 선발}

\author{
김동환 ${ }^{1} \cdot$ 문재남 $^{2} \cdot$ 이슬 ${ }^{2} \cdot$ 이수원 $^{1} \cdot$ 문혜경 $^{3} \cdot$ 김귀영 ${ }^{1 *}$ \\ ${ }^{1}$ 경북대학교 식품외식산업학과, ${ }^{2}$ 경북대학교 식품공학부, ${ }^{3}$ 경북대학교 공동실험실습관
}

\begin{abstract}
The purpose of this study was to screen desirable yeast strains for alcoholic fermentation of tomato paste without sugar addition. The moisture, crude protein, crude fat, ash, and soluble nitrogen contents of the tomato paste (25 ${ }^{\circ}$ Brix) were found to be $67.33 \%, 1.90 \%, 0.03 \%, 0.02 \%$, and $30.72 \%$, respectively. Free sugars found in the paste were fructose and glucose. Most abundant free amino acids of the paste were glutamic, aspartic, and $\mathrm{\gamma}$-aminobutyric acids. Total seven yeast strains (Saccharomyces cerevisiae KDH (TWA), S. cerevisiae Lalvin ICVD-47 (TWB), S. cerevisiae Lalvin RC-212 (TWC), S. cerevisiae Lalvin K1-V1116 (TWD), $S$. bayanus Lalvin EC-1118 (TWE), S. cerevisiae Enoferm (TWF), and S. cerevisiae DJ97(KCTC8842P) (TWG)) were tasted for alcohol fermentation of the tomato paste. The highest alcohol content $(8.2 \%)$ and the lowest residual sugar content $\left(13.25{ }^{\circ}\right.$ Brix $)$ were observed in the tomato paste fermented using the $S$. cerevisiae Lalvin ICVD-47 strain (TWB) after 3 day and 4 day of fermentation, respectively. Sugar and reducing sugar contents, and $\mathrm{pH}$ of the tomato paste were not remarkably affected by the difference in yeast strains used, showing $13.25 \sim 13.45{ }^{\circ}$ Brix, $28.37 \sim 28.48 \mathrm{mg} / \mathrm{mL}$, and $4.43 \sim 4.54$, respectively, after 4 day of fermentation. Color and total acid content were significantly affected by the types of yeast strains and fermentation time, but the numerical changes were negligible. These results indicate that TWB would be the suitable strain for alcoholic fermentatiom of tomato paste based on its highest alcohol production and the lowest residual sugar content produced during fermentation.
\end{abstract}

Key words : sugar-free, tomato concentration, yeast, alcoholic fermentation

\section{서 론}

토마토(tomato)의 학명은 Lycopersicon esculentum MILL 로 persicon과 카르티노이드계 색소인 lycopene의 합성어

*Corresponding author. E-mail : gykim@knu.ac.kr Phone : 82-54-530-1301, Fax : 82-54-530-1309

Received 31 May 2016; Revised 1 July 2016; Accepted 5 July 2016.

Copyright (c) The Korean Society of Food Preservation. All rights reserved. esculentum이며「먹을 수 있다」는 뜻을 가지고 있다(1). 가지과에 속하는 1 년생 작물로서 남미의 서부고원지대가 원산지이며, 우리나라에 들어온 시기는 지봉유설(芝峰類 說)에 수록 된 것으로 보아 17세기 초 쯤으로 짐작된다(2). 토마토는 온대지방에서 주로 재배되고 해마다 그 생산량이 증가하고 있으며, 우리나라의 기후와 풍토에 적합하여 전 국에 걸쳐 재배가 되고 있다(3). 토마토는 인간조직에서 발견되는 14 개 정도의 카르티노이드 중 9 가지를 함유하고 있으며, 이 중 항산화 활성이 뛰어난 라이코펜과 체내에 흡수되어 비타민 $\mathrm{A}$ 로 전환되는 베타-카로틴과 알파-카로 
틴, 루틴 등을 함유하고 있다. 토마토에 풍부한 라이코펜은 천연물에서 찾을 수 있는 카로티노이드의 일종으로 수박, 구아바, 붉은 고추 등에 비해 라이코펜을 많이 함유하고 있다(4). 토마토에만 유일하게 존재하는 물질로는 tomatine 과 dehydrotomatine이 있으며 이들은 항암 화학요법에 효과 가 있는 것으로 보고되고 있다(5).

최근 와인은 건강에 대한 관심증가, 생활수준의 향상과 여성의 사회진출, 저가의 와인공급 등으로 와인의 대중화 를 불러왔으며, 주류 선택권이 여성으로 바뀌면서 알코올 도수가 높은 주류보다 저알코올 주류가 선호되면서 소비도 증가하는 추세이다. 이에 국내에서도 다양한 생리활성 물 질이 함유된 원료를 이용하여 와인을 개발하고자 진행되고 있는 다양한 연구로는 감와인(6), 갈대 뿌리 로제 스파클링 와인(7), 참외와인(8), 복분자 와인(9), 블루베리 와인(10), 흑마늘 와인(11), 오디 와인(12), 벌꿀 와인(13) 등이 있다.

이에 본 연구에서는 생리활성 물질이 다량 함유되어 있 는 토마토 농축액을 제조한 후 무가당 알코올 발효에 따른 균주 선발을 하여 토마토 와인 제조의 기초자료로 활용하고 자 한다.

\section{재료 및 방법}

\section{실험재료}

본 실험에 사용한 토마토 농축액은 친환경 토마토(경북 일대)를 구입하여 세척 후 이물질과 꼭지를 제거한 후 습식 분쇄기(HCM-250, Hansung Pulverzing Machinery Co., Ltd., Gwangju, Korea)로 분쇄하여 착즙기(HSJ-120, Hansung Pulverzing Machinery Co., Ltd., Gwangju, Korea)로 착즙한 액을 진공농축기(CEP-1, OKAWARA MFG. Co., Ltd., Tokyo, JAPAN)를 이용하여 $25{ }^{\circ} \mathrm{Brix}$ 로 농축하였다. 토마토 농축액은 $-25^{\circ} \mathrm{C}$ 냉동고에 보관하면서 토마토 와인 제조를 위한 재료로 사용하였다.

\section{토마토 농축액의 품질 특성 분석}

일반 성분 분석

토마토 농축액의 일반성분 분석은 $\mathrm{AOAC}$ 법(14)에 따라 실시하였다. 수분 함량은 $105^{\circ} \mathrm{C}$ 상압 가열 건조법, 조단백질 은 Kjeldahl 질소 정량법, 조지방은 Soxhlet 추출법, 조회분 은 직접 회화법으로 측정하여 백분율로 나타내었다. 가용 성 무질소물은 수분, 조단백질, 조지방 및 조회분을 제외한 값으로 구하였다.

\section{유리당 함량 분석}

유리당은 Wilson과 Work 방법(15)에 따라 시료를 약 5 $\mathrm{g}$ 씩 정확히 칭량하여 $80 \%$ 에탄올 용액 $100 \mathrm{~mL}$ 를 가하여 환류 냉각 추출 장치에 넣어 부착된 heating mantle에서 8 $0^{\circ} \mathrm{C}, 2$ 시간 동안 당 성분을 반복 추출 후 Whatman No. 5 로 여과한 여액을 진공 농축 건조 $\left(40^{\circ} \mathrm{C}\right)$ 후 증류수 $5 \mathrm{~mL}$ 로 정용한 다음 $0.45 \mu \mathrm{m}$ membrane filter로 여과한 후 HPLC (Waters 2695, Waters Co., Milford, MA, USA)로 분석하였 다. 이때 column은 carbohydrate column(ID $3.96 \times 300 \mathrm{~mm}$, Waters Co., Milford, MA, USA), column oven 온도 $35^{\circ} \mathrm{C}$, mobile phase $75 \%$ acetonitrile, flow rate $1.0 \mathrm{~mL} / \mathrm{min}$, 시료 주입량 $10 \mu \mathrm{L}$ 의 조건으로 Refractive Index(RI) detector (Waters 2414, Waters Co., Milford, MA, USA)에서 검출하였 다. 표준품은 xylose, fructose, glucose, sucrose, arabinose, maltose, mannose 및 lactose(Sigma, St. Louis, MO, USA)를 일정량씩 혼합하여 증류수에 녹여 표준용액으로 사용하였 다. 표준품과 시료의 당 성분은 머무른 시간(Rt)을 직접 비교하여 확인하였고, 각 표준품의 검량 곡선을 작성하여 peak의 면적으로 개별 당 성분의 함량을 산출하였다.

\section{유리 아미노산 함량 분석}

유리 아미노산 함량을 분석하기 위해 시료를 $10 \mathrm{~mL}$ 에 ethanol $30 \mathrm{~mL}$ 를 가한 다음 하룻밤 실온에서 방치시켜 단백 질을 침전 - 제거하고 상층액을 $8,000 \mathrm{rpm}$ 에서 15 분간 원심 분리한 후 상등액을 취하여 $45^{\circ} \mathrm{C}$ 에서 감압 농축하였다. 0.2 $\mathrm{M}$ sodium citrate buffer( $\mathrm{pH}$ 2.2) 용액 $10 \mathrm{~mL}$ 정용하고, Sepak $\mathrm{C} 18$ 처리한 후 $0.45 \mu \mathrm{m}$ membrane filter로 재여과한 시료액 을 automatic amino acid analyzer(Biochrom-30, Biochrom Ltd., Cambridge, England)로 분석하였다. 이때 분석조건으 로 buffer solution은 lithium citrate buffer를 사용하였고 buffer flow rate는 $0.33 \mathrm{~mL} / \mathrm{min}$, ninhydrin flow rate는 0.33 $\mathrm{mL} / \mathrm{min}$, column temp. 은 $37^{\circ} \mathrm{C}$, injection volume은 $40 \mu \mathrm{L}$ 로 하였다.

\section{발효 균주 배양}

토마토 농축액의 발효에 적합한 효모를 선발하기 위하여 본 실험에서 분리한 Saccharomyces cerevisiae $\mathrm{KDH}(\mathrm{A})$ 와 계명대학교 발효공학실에서 보관중인 Lalvin사(Lallemand, Inc., Montreal, Canada)의 Saccharomyces cerevisiae Lalvin ICV D-47(B), Saccharomyces cerevisiae Lalvin RC-212(C), Saccharomyces cerevisiae Lalvin K1-V1116(D), Saccharomyces bayanus Lalvin EC-1118(E), Saccharomyces cerevisiae Enoferm(F) 및 Saccharomyces cerevisiae DJ97(KCTC8842P) $(\mathrm{G})$ 를 분양받아 총 7 종을 $\mathrm{YPD}$ (yeast extract $1 \%$, peptone $2 \%$, glucose $2 \%$, agar $2 \%, \mathrm{pH} 6.0)$ 배지에 계대 배양 $\left(30^{\circ} \mathrm{C}\right.$ 에 서 24시간)하여 냉동실에 보관하면서 본 실험에 사용하였다.

\section{주모 배양}

주모의 배양은 냉동 보관 중인 토마토농축액을 사용하여 계대 배양한 후 보관중인 균주 7 종을 $10{ }^{\circ} \mathrm{Brix}$ 토마토농축액 에 접종하고 $30^{\circ} \mathrm{C}$ 에서 24 시간 배양한 후 알코올 발효의 
주모로 사용하였다.

\section{알코올 함량 측정}

국세청기술연구소 주류분석규정(16)에 따라 발효가 끝 난 술덧을 $100 \mathrm{~mL}$ 취하여 증류수 $50 \mathrm{~mL}$ 와 혼합하여 증류수 플라스크에 넣고 증류를 실시하여 증류액 약 $80 \mathrm{~mL}$ 를 받은 다음 증류수로 $100 \mathrm{~mL}$ 로 정용하여 주정계(alcohol hydrometer, DK-AL-S/L, Daekwng Inc., Seoul, Korea)로 알코올 농도를 측정하고 Gay-Lucsac 표를 이용하여 $15^{\circ} \mathrm{C}$ 로 보정하여 알코 올 함량을 구하였다.

\section{당도 측정}

시료의 당도 측정은 굴절당도계(ATC-1E, Atago Co., Ltd., Tokyo, Japan)를 사용하여 3회 반복 측정하여 평균값 으로 나타내었다.

\section{환원당 함량 측정}

환원당 함량의 측정은 dinitrosalicylic acid(DNS) 법에 의 한 비색법(17)으로 측정하였다. 시료 $0.1 \mathrm{~mL}$ 에 증류수 0.9 $\mathrm{mL}, \mathrm{DNS}$ 시약 $1 \mathrm{~mL}$ 를 차례로 취하고 잘 섞은 후 끓는 물 수조에서 15 분 정도 반응하게 한 다음 $20^{\circ} \mathrm{C}$ 의 수조에 15 분 정도 냉각하였다. 발색된 반응액에 증류수 $3 \mathrm{~mL}$ 를 넣어 희석한 후 분광 광도계(MultiSpec-1500, Shimadzu, Kyoto, Japan) $546 \mathrm{~nm}$ 에서 흡광도를 측정하였다. 환원당 함량은 표준 검량 곡선을 사용하여 glucose에 대한 함량 $(\mathrm{mg} / \mathrm{mL})$ 로 환산하여 계산하였다.

\section{$\mathrm{pH}$ 측정}

$\mathrm{pH}$ 의 측정은 시료 $10 \mathrm{~mL}$ 를 검체하여 $\mathrm{pH}$ meter(PHM210 Standard pH Meter, Radiometer analytical SAS., Villeurbanne, France)를 사용하여 측정하였다.

\section{총산 측정}

총산의 함량은 $\mathrm{AOAC}$ 법(18)에 의하여 시료 $1 \mathrm{~mL}$ 를 취하 여 $1 \%$ phenolphtalein을 지시약으로 첨가하여 $\mathrm{pH}$ 가 8.3에 도달할 때까지 $0.1 \mathrm{~N} \mathrm{NaOH}$ 용액으로 적정한 후 $\mathrm{NaOH}$ 소모량을 다음 식에 적용하여 lactic acid(\%) 함량으로 환산 하여 구하였다.

$$
\begin{gathered}
\left.\begin{array}{c}
\text { 총산 }(\%) \\
\text { (lactic acid) }
\end{array}\right) \\
\text { 소요된 } 0.1 \mathrm{~N} \mathrm{NaOH} \text { 의 } \mathrm{mL} \times 0.1 \mathrm{~N}-\mathrm{NaOH} \text { 의 factor } \times 0.009 \times \text { 희석 배수 } \\
\text { 시료 채취량(mL) }
\end{gathered} \times 100
$$

\section{색도 측정}

색도의 측정은 Color difference meter(CR-300, Minolta Co., Ltd., Osaka, Japan)를 사용하여 측정하였으며, 그 값을 Hunter' color value인 명도(lightness, L)와 적색도(redness, a), 황색도(yellowness, b)를 측정하였다. 이때 표준색으로는
$\mathrm{L}$ 값이 $99.95, \mathrm{a}$ 값이 0.06 및 $\mathrm{b}$ 값이 0.10 인 표준 백색판을 사용 하였다.

\section{결과 및 고찰}

\section{토마토 농축액의 품질 특성}

일반 성분 분석

토마토 와인을 제조할 토마토 농축액 $\left(25^{\circ} \mathrm{Brix}\right)$ 의 일반성 분을 분석한 결과를 Table 1에 나타내었다. 수분 함량은 $67.33 \%$, 조단백질 함량은 $1.90 \%$, 조지방 함량은 $0.03 \%$, 조 회분 함량은 $0.02 \%$, 가용성 무질소물은 $30.72 \%$ 로 나타났다.

Table 1. Proximate composition of tomato concentrate

\begin{tabular}{cccccc} 
& & & & (unit: \%) \\
\hline Sample & Moisture & $\begin{array}{c}\text { Crude } \\
\text { protein }\end{array}$ & Crude fat & Crude ash & $\begin{array}{c}\text { N-free } \\
\text { extracts }\end{array}$ \\
\hline $\begin{array}{c}\text { Tomato } \\
\text { concentrate }\end{array}$ & $67.33 \pm 2.85^{1)}$ & $1.90 \pm 0.05$ & $0.03 \pm 0.00$ & $0.02 \pm 0.00$ & $30.72 \pm 1.26$ \\
\hline
\end{tabular}

${ }^{1)}$ Values are expressed as means $\pm \mathrm{SD}(\mathrm{n}=3)$.

\section{유리당 함량 분석}

토마토 와인을 제조할 토마토 농축액 $\left(25^{\circ} \mathrm{Brix}\right)$ 의 유리당 함량을 분석한 결과는 Table 2에 나타내었다. 유리당 중 fructose, glucose가 함유되어 있는 것으로 나타났으며, xylose, mannose, sucrose, maltose는 함유하고 있지 않은 것으로 나타났다. Glucose가 $11.10 \mathrm{~g} / 100 \mathrm{~g}$ 의 함유량을 보였 으며, fructose는 $10.42 \mathrm{~g} / 100 \mathrm{~g}$ 의 함유량을 나타내었다. Kim 등(19)의 연구에 따르면 토마토 과실에 가장 많이 함유된 당은 fructose와 glucose 라는 보고는 본 실험의 토마토 농축 액이 함유한 유리당 조성과 같은 경향을 나타내었다. 이상 의 결과 토마토농축액의 함유 당은 효모가 이용할 수 있는 fructose와 glucose가 주로 구성되어 있어 보당을 하지 않고 도 알코올 발효가 잘 이루어질 것으로 판단된다.

Table 2. Free sugar contents of tomato concentrate

\begin{tabular}{cc} 
& (unit: $\mathrm{g} / 100 \mathrm{~g}$ ) \\
\hline Free sugar & Tomato concentrate \\
\hline Xylose & $\mathrm{ND}^{1)}$ \\
Fructose & $10.42 \pm 0.47^{2)}$ \\
Mannose & $\mathrm{ND}$ \\
Glucose & $11.10 \pm 0.51$ \\
Sucrose & $\mathrm{ND}$ \\
Maltose & $\mathrm{ND}$ \\
\hline
\end{tabular}

\footnotetext{
${ }^{1)} \mathrm{ND}$, Not Detected.

${ }^{2)}$ Values are expressed as means \pm SD ( $n=3$ ).
} 
유리 아미노산 함량 분석

토마토 와인을 제조할 토마토 농축액 $\left(25^{\circ} \mathrm{Brix}\right)$ 의 유리 아미노산 분석 결과는 Table 3 에 나타내었다. 유리아미노산 이 총 19종 있는 것으로 나타났으며, 그 중에서 glutamic acid가 $814.7 \mathrm{mg} / 100 \mathrm{~g}$ 로 가장 많이 함유되어 있고, aspatic acid $217.3 \mathrm{mg} / 100 \mathrm{~g}$, $\mathrm{z}$-aminobutyric acid(GABA) 186.1 $\mathrm{mg} / 100 \mathrm{~g}$ 순으로 함유되어 있는 것으로 나타났다. 총 아미 노산 함량은 $1,751.3 \mathrm{mg} / 100 \mathrm{~g}$ 을 함유하고 있으며, 필수아미 노산이 $216.6 \mathrm{mg} / 100 \mathrm{~g}$ 으로 총 아미노산의 $12.37 \%$ 의 함유 비율을 나타내었다. Kim과 $\mathrm{Ahn}(20)$ 의 방울토마토 라이코 펜 품종의 유리아미노산의 분석결과 18 종의 아미노산이 함유 중 L-글루탐산, $\mathrm{L}-$ 글루타민, $\mathrm{L}-$ 아스파르트산 등의 순 으로 조성되어 있는 보고와 본 실험의 결과와 유사한 경향 을 나타내었고, Lee 등(21)은 일반 토마토의 원물 유리아미 노산 함량을 측정한 결과 $\mathrm{L}-\mathrm{Glu}$ 가 $13.67 \mathrm{mg} / 100 \mathrm{~g}$ 을 함유되 어 아미노산 중 가장 많은 함유량을 나타내고 있어 본 연구 의 결과와 유사하였다.

Table 3. Free amino acid contents of tomato concentrate (unit: $\mathrm{mg} / 100 \mathrm{~g}$ )

\begin{tabular}{cc}
\hline Free amino acid & Tomato concentrate \\
\hline Aspartic acid & $217.32 \pm 12.54^{1)}$ \\
Threonine & $33.14 \pm 1.09$ \\
Serine & $41.83 \pm 2.85$ \\
Glutamic acid & $814.70 \pm 23.46$ \\
Glycine & $9.03 \pm 0.81$ \\
Alanine & $45.92 \pm 1.95$ \\
a-aminobutyric acid & $8.24 \pm 0.54$ \\
Valine & $34.33 \pm 2.15$ \\
Methionine & $10.04 \pm 0.49$ \\
Isoleucine & $15.92 \pm 0.87$ \\
Leucine & $22.54 \pm 1.65$ \\
Tyrosine & $44.81 \pm 3.12$ \\
Phenylalanine & $48.13 \pm 1.99$ \\
g-aminobutyric acid & $186.16 \pm 10.05$ \\
Ethanolamine & $11.45 \pm 0.78$ \\
Ammonium chloride & $120.21 \pm 7.45$ \\
Lysine & $34.30 \pm 1.59$ \\
Histidine & $28.44 \pm 2.34$ \\
Arginine & $25.32 \pm 1.52$ \\
\hline Total amino acid & $1,726.51$ \\
\hline Essential amino acids & 252.16 \\
\hline
\end{tabular}

${ }^{1)}$ Values are expressed as means $\pm \mathrm{SD}(\mathrm{n}=3)$.

\section{알코올 함량}

토마토 농축액을 이용한 알코올 발효에 따른 균주 선별
을 위해 $30^{\circ} \mathrm{C}$ 에서 발효한 토마토 와인의 알코올 함량의 변화를 Fig. 1에 나타내었다. 알코올 발효 결과 대부분의 균주는 발효 3일째 8.00 8.20\%로 높은 알코올 함량을 보였 으며, TWA(S. cerevisiae $\mathrm{KDH})$ 는 4일째 가장 높은 함량으로 $8.03 \%$ 를 나타내었다. 사용 균주 중 $\mathrm{TWB}(S$. cerevisiae ICVD-47)는 $8.20 \%, \operatorname{TWG}(S$. cerevisiae DJ97)은 $8.13 \%$, $\operatorname{TWE}(S$. cerevisiae Lalvin EC-1118)는 8.08\% 순으로 높은 알코올 함량을 나타내었다. 이러한 결과 Roh 등(22)이 포도 주를 제조할 때 S. serevisiae Fermivin 포함한 효모 12종 모두 알코올 함량이 $12 \%$ 내외로 효모의 종류에 따른 큰 차이는 없다고 보고한 것과는 달리 본 실험에서 사용한 균주는 $8 \%$ 로 조금 낮은 값을 보였으며, 효모의 종류에 따라 큰 차이는 없었다. $\operatorname{Kim}$ 과 $\operatorname{Kim}(12)$ 은 오디 알코올 발효 초기 농도 $24{ }^{\circ} \mathrm{Brix}$ 알코올 함량이 $10.5 \sim 11.5 \%$ 로 보고하였는데 본 실험 결과보다 조금 높은 값을 나타내었으며, 이것은 원료와 보당의 차이에서 오는 결과로 사료된다.

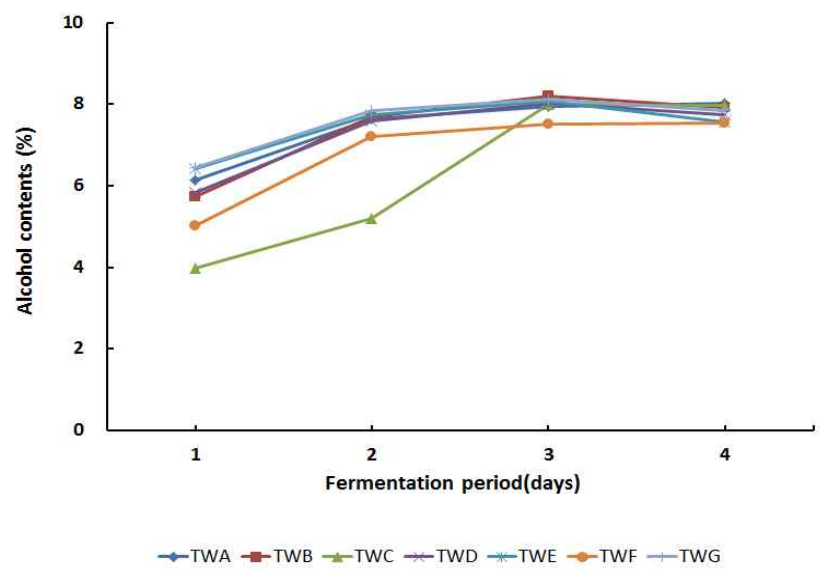

Fig. 1. Alcohol contents of tomato wine fermented with different yeasts.

TWA, Tomato wine in fermentation by $S$. cerevisiae KDH; TWB, Tomato wine in fermentation by $S$ cerevisiae Lalvin ICVD-47; TWC, Tomato wine in fermentation by $S$. cerevisiae Lalvin RC-212; TWD, Tomato wine in fermentation by $S$. cerevisiae Lalvin K1-V1116; TWE, Tomato wine in fermentation by $S$. bayanus Lalvin EC-1118; TWF, Tomato wine in fermentation by $S$. Enoferm TWG, Tomato wine in fermentation by $S$. cerevisiae DJ97(KCTC8842P)

당 도

토마토 농축액을 이용한 알코올 발효에 따른 균주 선발 을 위해 $30^{\circ} \mathrm{C}$ 에서 발효한 토마토 와인의 당도 함량은 Fig. 2 에 나타내었다. 당도 측정 결과 1 일차에서는 $\mathrm{TWC}(S$. cerevisiae Lalvin RC-212)가 $17.93{ }^{\circ} \mathrm{Brix}$ 로 가장 높은 값을 나타내었으며, $\operatorname{TWG}(S$. cerevisiae DJ97, KCTC8842P)가 $14.43{ }^{\circ} \mathrm{Brix}$ 로 가장 낮은 값을 보였다. 2 일차 당도는 13.35 14.58 ${ }^{\circ} \mathrm{Brix}$ 를 나타내었고, 3 일차에서 13.30 13.58 ${ }^{\circ} \mathrm{Brix}$ 로 각 균주의 당 함량은 비슷한 경향을 나타내었으며, 발효 4일차에서도 TWB(S. cerevisiae ICVD-47)는 13.25로 가장 낮은 잔류당 함량을 나타내었고, 각 균주의 당도는 


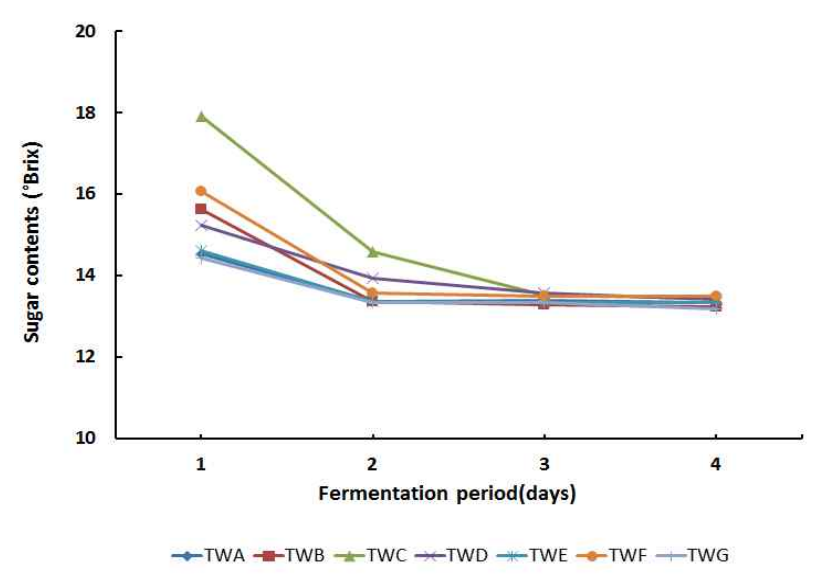

Fig. 2. Sugar contents of tomato wine fermented with different yeasts.

TWA, Tomato wine in fermentation by $S$. cerevisiae KDH; TWB, Tomato wine in fermentation by $S$. cerevisiae Lalvin ICVD-47; TWC, Tomato wine in fermentation by $S$. cerevisiae Lalvin RC-212; TWD, Tomato wine in fermentation by $S$. cerevisiae Lalvin K1-V1116; TWE, Tomato wine in fermentation by $S$. bayanus Lalvin EC-1118; TWF, Tomato wine in fermentation by $S$. Enoferm, TWG, Tomato wine in fermentation by $S$. cerevisiae DJ97(KCTC8842P).

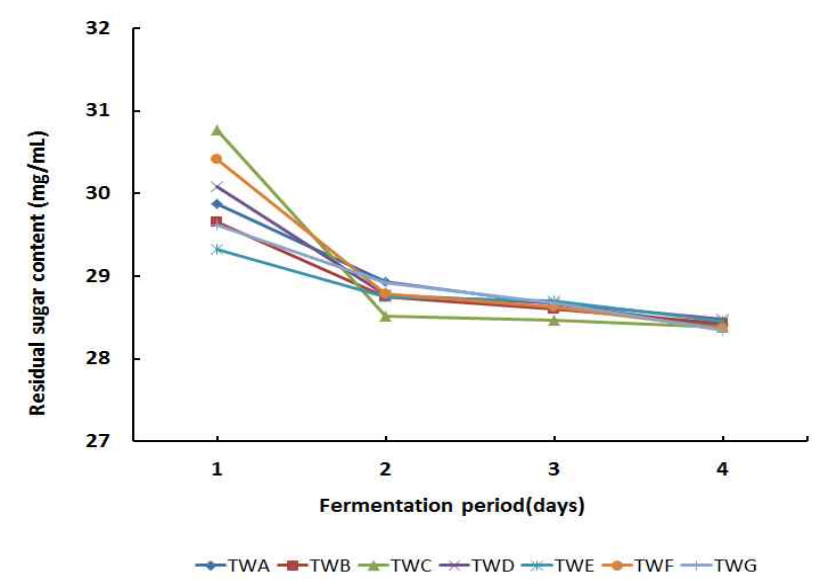

Fig. 3. Residual sugar contents of tomato wine fermented with different yeasts.

TWA, Tomato wine in fermentation by $S$. cerevisiae KDH; TWB, Tomato wine in fermentation by $S$. cerevisiae Lalvin ICVD-47; TWC, Tomato wine in fermentation by $S$. cerevisiae Lalvin RC-212; TWD, Tomato wine in fermentation by $S$. cerevisiae Lalvin K1-V1116; TWE, Tomato wine in fermentation by $S$. bayanus Lalvin EC-1118; TWF, Tomato wine in fermentation by $S$. Enoferm, TWG, Tomato wine in fermentation by $S$. cerevisiae DI97(KCTC8842P).

13.25 13.45 ${ }^{\circ} \mathrm{Brix}$ 로 비슷한 경향을 나타내었다. 알코올 함 량의 증가에 당의 함량은 상대적으로 감소가 뚜렷히 나타나 는데 비해 본 실험에서는 1 일차 이후에는 모든 균주에서 비슷한 값을 나타내었는데 이는 원료의 차이에서 오는 결과 로 판단된다. Jang 등(23)은 토마토를 이용한 알코올 발효는 초기당도 $20 \sim 22{ }^{\circ} \mathrm{Brix}$ 가 적정할 것으로 보고하였으며, 이후 숙성, 저장 및 관능적인 특성을 고려하여 초기당도 조정을 위해 설탕을 첨가하여 보당을 하였고, 본 연구에서는 설탕 을 보당하지 않고 농축하여 사용하였기 때문에 발효와 숙성 에서 관능적인 특성의 차이가 있을 것으로 판단된다. 당도
를 측정한 결과 사용한 균주 모두 비슷한 값을 나타냈으며, 균주간 유의적인 차이는 없는 것으로 나타났다. 이러한 결 과 당은 균주 선별에 큰 영향을 주지 않는 것으로 나타났다.

\section{환원당 함량}

토마토 농축액을 이용한 알코올 발효에 따른 균주 선발 을 위해 $30^{\circ} \mathrm{C}$ 에서 발효한 토마토 와인의 환원당 함량은 Fig. 3에 나타내었다. 환원당 분석결과 1 일차에서는 모든 구간에서 $29.32 \sim 30.77 \mathrm{mg} / \mathrm{mL}$ 의 값을 나타내 알코올 발효 균주에 따른 큰 차이를 나타내지 않았다. TWC $(S$. cerevisiae Lalvin RC-212)는 발효 1 일차 $30.77 \mathrm{mg} / \mathrm{mL}$ 로 가장 높은 값을 나타내었고, 발효 2일차에서는 $28.52 \mathrm{mg} / \mathrm{mL}$ 로 가장 많이 감소하였고, 발효 3일차 $28.47 \mathrm{mg} / \mathrm{mL}$, 4일차는 28.38 $\mathrm{mg} / \mathrm{mL}$ 으로 급격히 감소한 2 일차 이후는 변화를 나타내지 않았다. 4일차에서 모든 균주의 환원당 함량은 28.35 28.48 $\mathrm{mg} / \mathrm{mL}$ 의 값을 나타내어 알코올 발효 균주에 따른 차이가 없는 것으로 나타났으며, 발효 기간이 증가함에 따라 환원 당 함량은 조금씩 낮아지는 경향을 나타내었다. Hwang 등 (8)의 연구에 따르면 전처리 방법을 달리하여 제조한 참외 와인의 6 일간의 알코올 발효과정을 살펴본 결과 환원당 함량은 발효 2 일차 이후부터 급격히 감소하여 발효 5일차 이후 환원당 함량 변화가 나타나지 않았다는 결과는 본 연구와 유사한 경향을 나타내었다.

$\mathrm{pH}$

토마토 농축액을 이용한 알코올 발효에 따른 균주 선발 을 $30^{\circ} \mathrm{C}$ 에서 발효한 토마토 와인의 $\mathrm{pH}$ 는 Fig. 4 에 나타내었 다. $\mathrm{pH}$ 를 측정한 결과 사용한 균주 모두 1 일차에서 4 일차까 지 비슷한 값을 나타내었으며, $\mathrm{pH}$ 는 4.31 4.55의 값을 나타

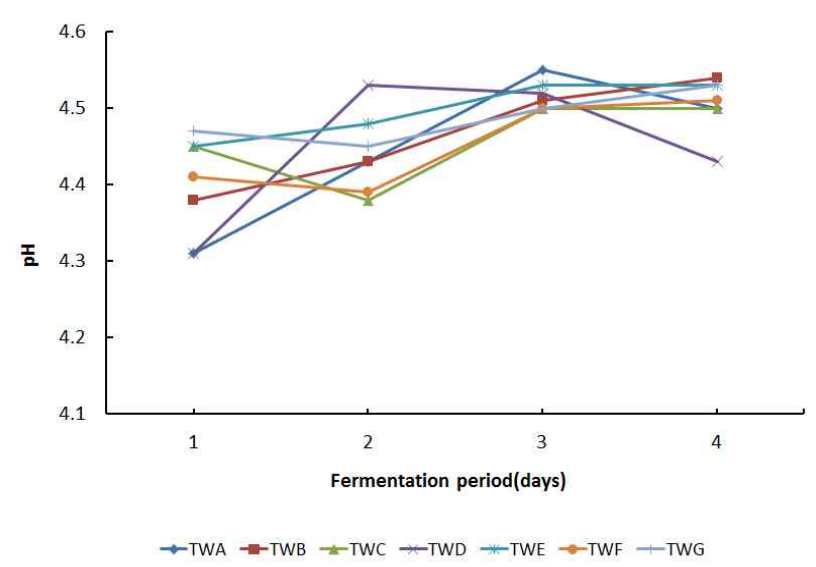

Fig. 4. $\mathrm{pH}$ of tomato wine fermented with different yeasts.

TWA, Tomato wine in fermentation by $S$. cerevisiae KDH; TWB, Tomato wine in fermentation by $S$ cerevisiae Lalvin ICVD-47; TWC, Tomato wine in fermentation by $S$. cerevisiae Lalvin RC-212; TWD, Tomato wine in fermentation by $S$. cerevisiae Lalvin K1-V1116; TWE, Tomato wine in fermentation by $S$. bayanus Lalvin EC-1118; TWF, Tomato wine in fermentation by $S$. Enoferm TWG, Tomato wine in fermentation by $S$. cerevisiae DJ97(KCTC8842P) 
내었다. 따라서 균주에 따른 $\mathrm{pH}$ 의 차이는 없는 것으로 나타 났다. $\mathrm{Kim}$ 등(24)은 산머루 와인의 $\mathrm{pH}$ 는 3.59로 보고 하였 으며, 포도와인의 경우 $\mathrm{pH}$ 가 3.6 이상이면 잡균이 발생 할 가능성이 높고, 반대로 $\mathrm{pH}$ 가 3.2 이하이면 지나치게 신맛이 난다고 보고하였으나 본 실험에서는 $\mathrm{pH}$ 4.43 4.54의 값이 나타나 조금 높은 값을 보여주었다. Woo 등(25)의 연구에서 도 균주를 달리한 참다래 와인의 발효 숙성 기간 중 $\mathrm{pH}$ 의 변화를 확인한 결과 발효 초기 모두 $\mathrm{pH} 3.35$ 3.36의 값을 나타내었으며, 발효가 진행되면서 꾸준히 증가하는 경향을 보이는 것으로 보고하였는데 본 연구에서도 유사한 경향을 나타내었다.

\section{총 산}

토마토 농축액을 이용한 알코올 발효에 따른 균주 선발 을 위해 $30^{\circ} \mathrm{C}$ 에서 발효한 토마토 와인의 총산은 Table 4 에 나타내었다. 총산을 측정한 결과 사용된 균주 모두 1 일차 $0.54 \sim 0.78$ 을 나타내었으며, 4 일차에서는 $0.43 \sim 0.56$ 으로 발 효가 진행됨에 따라 총산은 감소하는 경향을 나타내었고, 이러한 결과는 발효가 진행되는 과정이 정상적으로 이루어 졌다는 것을 의미하며 사용된 균주 모두 발효과정은 이상이 없는 것으로 나타났다. Woo 등(25)의 참다래 와인의 균주별 발효기간에 따른 총산측정 결과 총산은 발효가 진행됨에 따라 조금씩 증가하여 발효기간에 따른 상승 수치는 비슷한 것으로 보고된 것과 달리 본 연구에서는 모든 균주들의 총산이 발효 4일째 모두 조금씩 감소한 것으로 확인이 되었 다. 이는 참다래와 토마토농축액의 발효원료 특성의 차이 에서 나는 결과로 판단된다. Jang 등(23)은 와인의 총산은

Table 4. Total acidity of tomato wine fermented with different yeasts

\begin{tabular}{ccccc}
\hline Yeasts $^{1}$ & \multicolumn{4}{c}{ Fermentation period (days) } \\
\cline { 2 - 5 } & 1 & 2 & 3 & 4 \\
\hline TWA & $0.54 \pm 0.02^{2 \mathrm{~A} 33) \mathrm{d} 4)}$ & $0.52 \pm 0.01^{\mathrm{ABbc}}$ & $0.44 \pm 0.01^{\mathrm{Cd}}$ & $0.49 \pm 0.03^{\mathrm{Bbc}}$ \\
TWB & $0.78 \pm 0.01^{\mathrm{Aa}}$ & $0.50 \pm 0.08^{\mathrm{Bc}}$ & $0.56 \pm 0.02^{\mathrm{Bbc}}$ & $0.48 \pm 0.01^{\mathrm{Bcd}}$ \\
TWC & $0.73 \pm 0.04^{\mathrm{Acb}}$ & $0.62 \pm 0.01^{\mathrm{Ba}}$ & $0.54 \pm 0.01^{\mathrm{Cc}}$ & $0.57 \pm 0.05^{\mathrm{BCa}}$ \\
TWD & $0.69 \pm 0.03^{\mathrm{Ac}}$ & $0.57 \pm 0.01^{\mathrm{Bab}}$ & $0.57 \pm 0.02^{\mathrm{Bb}}$ & $0.50 \pm 0.04^{\mathrm{Cbc}}$ \\
TWE & $0.69 \pm 0.03^{\mathrm{Ac}}$ & $0.43 \pm 0.03^{\mathrm{Bd}}$ & $0.43 \pm 0.01^{\mathrm{Bd}}$ & $0.43 \pm 0.02^{\mathrm{Bd}}$ \\
TWF & $0.75 \pm 0.01^{\mathrm{Aab}}$ & $0.52 \pm 0.02^{\mathrm{Cbc}}$ & $0.64 \pm 0.02^{\mathrm{Ba}}$ & $0.55 \pm 0.02^{\mathrm{Cab}}$ \\
TWG & $0.69 \pm 0.02^{\mathrm{Ac}}$ & $0.50 \pm 0.02^{\mathrm{Bc}}$ & $0.42 \pm 0.01^{\mathrm{Cd}}$ & $0.48 \pm 0.02^{\mathrm{Bcd}}$ \\
\hline
\end{tabular}

${ }^{1)}$ TWA, Tomato wine in fermentation by $S$. cerevisiae $\mathrm{KDH}$; TWB, Tomato wine in fermentation by $S$. cerevisiae Lalvin ICVD-47; TWC, Tomato wine in fermentation by $S$ cerevisiae Lalvin RC-212; TWD, Tomato wine in fermentation by $S$. cerevisiae Lalvin K1-V1116; TWE, Tomato wine in fermentation by $S$ bayanus Lalvin EC-1118; TWF, Tomato wine in fermentation by $S$. Enoferm TWG, Tomato wine in fermentation by $S$ cerevisiae DJ97 (KCTC8842P).

${ }^{2)}$ Values are expressed as means $\pm \mathrm{SD}(\mathrm{n}=3)$.

3)A-C Values within the same row with different superscript letters are significantly different at $\mathrm{p}<0.05$.

${ }^{4) a-d}$ Values within the same column with different superscript letters are significantly different at $\mathrm{p}<0.05$.
맛을 결정하는 중요한 요소이며 총산 함량이 낮은 와인은 맛이 밋밋하고 보관 도중에 쉽게 상할 수 있는 반면 총산 함량이 높은 와인은 거칠고 신맛이 강하다고 보고하였다. 총산의 함량이 발효주의 품질 특성에 큰 영향을 미치고 있다는 것을 알 수 있다. 본 연구에서는 균주 서로간의 차이 가 없는 것으로 나타났다.

\section{색 도}

토마토 농축액을 이용한 알코올 발효에 따른 균주 선발 을 위해 $30^{\circ} \mathrm{C}$ 에서 발효한 토마토 와인의 색도 $\mathrm{L}, \mathrm{a}, \mathrm{b}$ 의 변화를 측정한 결과는 Table 5에 나타내었다. 색도를 측정 한 결과 명도(L 값)는 사용한 균주 모두 1 일차에서 4 일차까 지 비슷한 값을 나타내어 차이를 보이지 않는 것으로 나타

Table 5. Hunter's color of tomato wine fermented with different yeasts

\begin{tabular}{|c|c|c|c|c|c|}
\hline \multirow{2}{*}{$\begin{array}{l}\text { Hunter's } \\
\text { color }\end{array}$} & \multirow{2}{*}{ Yeasts $^{1}$} & \multicolumn{4}{|c|}{ Fermentation period (days) } \\
\hline & & 1 & 2 & 3 & 4 \\
\hline \multirow{7}{*}{ L } & TWA & $20.64 \pm 0.01^{2 / 23)(4)}$ & $19.83 \pm 0.12^{\mathrm{Cd}}$ & $20.67 \pm 0.07^{\mathrm{Ad}}$ & $20.27 \pm 0.03^{\mathrm{Be}}$ \\
\hline & TWB & $20.58 \pm 0.01^{\mathrm{Be}}$ & $21.04 \pm 0.09^{\mathrm{Aa}}$ & $20.40 \pm 0.05^{\mathrm{Cf}}$ & $20.67 \pm 0.03^{\mathrm{Bcd}}$ \\
\hline & TWC & $20.79 \pm 0.03^{\mathrm{Bd}}$ & $20.81 \pm 0.05^{\mathrm{Bb}}$ & $21.57 \pm 0.02^{\mathrm{Ab}}$ & $20.64 \pm 0.04^{\mathrm{Ccd}}$ \\
\hline & TWD & $21.18 \pm 0.08^{\mathrm{Bb}}$ & $19.77 \pm 0.03^{\mathrm{Cd}}$ & $21.70 \pm 0.02^{\mathrm{Aa}}$ & $21.12 \pm 0.11^{\mathrm{Bb}}$ \\
\hline & TWE & $20.95 \pm 0.08^{\mathrm{Bc}}$ & $21.05 \pm 0.01^{\mathrm{Aa}}$ & $20.39 \pm 0.04^{\mathrm{Df}}$ & $20.60 \pm 0.03^{\mathrm{Cd}}$ \\
\hline & TWF & $21.44 \pm 0.03^{\mathrm{Aa}}$ & $20.72 \pm 0.01^{\mathrm{cb}}$ & $21.34 \pm 0.04^{\mathrm{Bc}}$ & $21.28 \pm 0.05^{\mathrm{Ba}}$ \\
\hline & TWG & $20.96 \pm 0.02^{\mathrm{Ac}}$ & $20.28 \pm 0.02^{\mathrm{Dc}}$ & $20.52 \pm 0.01^{\mathrm{Ce}}$ & $20.71 \pm 0.02^{\mathrm{Bc}}$ \\
\hline \multirow{7}{*}{$\mathrm{a}$} & TWA & $1.32 \pm 0.07^{\mathrm{Ac}}$ & $1.27 \pm 0.01^{\mathrm{ABbc}}$ & $1.33 \pm 0.06^{\mathrm{Ab}}$ & $1.21 \pm 0.01^{\mathrm{Bbc}}$ \\
\hline & TWB & $1.53 \pm 0.01^{\mathrm{Aa}}$ & $1.20 \pm 0.08^{\mathrm{Cd}}$ & $1.33 \pm 0.04^{\mathrm{Bb}}$ & $1.22 \pm 0.01^{\mathrm{Cabc}}$ \\
\hline & TWC & $1.12 \pm 0.10^{\mathrm{ABd}}$ & $1.17 \pm 0.02^{\mathrm{Ad}}$ & $1.02 \pm 0.01^{\mathrm{Bd}}$ & $1.11 \pm 0.02^{\mathrm{ABd}}$ \\
\hline & TWD & $1.31 \pm 0.01^{\mathrm{Ac}}$ & $1.20 \pm 0.04^{\mathrm{Bd}}$ & $1.19 \pm 0.02^{\mathrm{Bc}}$ & $1.25 \pm 0.05^{\mathrm{ABab}}$ \\
\hline & TWE & $1.52 \pm 0.03^{\mathrm{Aa}}$ & $1.22 \pm 0.01^{\mathrm{Ced}}$ & $1.36 \pm 0.04^{\mathrm{Bab}}$ & $1.22 \pm 0.01^{\mathrm{Cabc}}$ \\
\hline & TWF & $1.39 \pm 0.01^{\mathrm{Abc}}$ & $1.32 \pm 0.01^{\mathrm{Bab}}$ & $1.39 \pm 0.01^{\mathrm{Aab}}$ & $1.16 \pm 0.03^{\mathrm{Cod}}$ \\
\hline & TWG & $1.42 \pm 0.01^{\mathrm{Ab}}$ & $1.35 \pm 0.01^{\mathrm{ABa}}$ & $1.41 \pm 0.05^{\mathrm{Aa}}$ & $1.30 \pm 0.09^{\mathrm{Ba}}$ \\
\hline \multirow{7}{*}{ b } & TWA & $1.09 \pm 0.01^{\mathrm{Abc}}$ & $0.89 \pm 0.01^{\mathrm{Ba}}$ & $0.78 \pm 0.01^{\mathrm{Da}}$ & $0.70 \pm 0.04^{\mathrm{Da}}$ \\
\hline & TWB & $1.20 \pm 0.05^{\mathrm{Aa}}$ & $0.74 \pm 0.04^{\mathrm{Bc}}$ & $0.73 \pm 0.01^{\mathrm{Bab}}$ & $0.72 \pm 0.02^{\mathrm{Ba}}$ \\
\hline & TWC & $0.87 \pm 0.02^{\mathrm{Ae}}$ & $0.59 \pm 0.02^{\mathrm{Be}}$ & $0.52 \pm 0.04^{\mathrm{Cd}}$ & $0.47 \pm 0.02^{\mathrm{Dd}}$ \\
\hline & TWD & $0.98 \pm 0.02^{\mathrm{Ad}}$ & $0.66 \pm 0.02^{\mathrm{Bd}}$ & $0.62 \pm 0.03^{\mathrm{Bc}}$ & $0.62 \pm 0.03^{\mathrm{Bbc}}$ \\
\hline & TWE & $1.14 \pm 0.06^{\mathrm{Ab}}$ & $0.74 \pm 0.04^{\mathrm{Bc}}$ & $0.72 \pm 0.01^{\mathrm{Bb}}$ & $0.67 \pm 0.06^{\mathrm{Bab}}$ \\
\hline & TWF & $0.96 \pm 0.03^{\mathrm{Ad}}$ & $0.83 \pm 0.05^{\mathrm{Bb}}$ & $0.73 \pm 0.06^{\mathrm{Cab}}$ & $0.60 \pm 0.03^{\mathrm{Dc}}$ \\
\hline & TWG & $1.05 \pm 0.01^{\mathrm{Ac}}$ & $0.80 \pm 0.03^{\mathrm{Bb}}$ & $0.77 \pm 0.01^{\mathrm{Bab}}$ & $0.71 \pm 0.03^{\mathrm{Ca}}$ \\
\hline
\end{tabular}

${ }^{1)}$ TWA, Tomato wine in fermentation by $S$. cerevisiae $\mathrm{KDH}$; TWB, Tomato wine in fermentation by $S$ cerevisiae Lalvin ICVD-47; TWC, Tomato wine in fermentation by $S$. cerevisiae Lalvin RC-212; TWD, Tomato wine in fermentation by $S$. cerevisiae Lalvin K1-V1116; TWE, Tomato wine in fermentation by $S$ bayanus Lalvin EC-1118; TWF, Tomato wine in fermentation by $S$. Enoferm, TWG, Tomato wine in fermentation by $S$ cerevisiae DJ97(KCTC8842P).

${ }^{2)}$ Values are expressed as means \pm SD $(\mathrm{n}=3)$.

${ }^{3) A-D}$ Values within the same row with different superscript letters are significantly different at $\mathrm{p}<0.05$

${ }^{4) a f}$ Values within the same column with different superscript letters are significantly different at $p<0.05$. 
났다. 이 결과 명도(L 값)는 발효초기와 종료 후에도 큰 변화가 없는 것으로 나타났다. 적색도(a 값)는 사용한 균주 모두 발효 1 일차의 값이 가장 높게 나타났으며 $2,3,4$ 일차의 값은 거의 변화가 없이 비슷한 경향을 나타내었다. 이 결과 균주 선별에 있어서 적색도(a 값)는 큰 영향을 주지 않는 것으로 나타났다. 황색도(b 값)는 사용 균주 모두 발효시간 이 증가할수록 값이 조금씩 낮아지는 경향을 보였으며 사용 된 균주 간에는 차이가 없는 것으로 나타났다. 명도(L 값), 적색도(a 값) 및 황색도(b 값)는 균주선별에 큰 영향을 주지 않는 것으로 나타났다. Kim 등(26)은 색도는 와인 품질평가 의 중요 항목 중 하나로 폴리페놀 함량이 미생물 활성 등에 영향을 받는다고 하였으며, Bae 등(27)의 보고서에서도 포 도주의 페놀함량과 색도의 상관관계는 명도와 황색도는 총 페놀함량과 음의 상관관계를, 적색도는 양의 상관관계 를 보였다. 포도주보다 색이 월등히 검붉은 오디발효주에 서는 포도주의 색도에서 나타나는 이러한 상관관계를 찾아 볼 수 없다고 보고되었다. 본 실험에서는 발효기간 동안 명도(L 값)와 적색도(a 값)는 비슷한 값을 나타내었고, 황색 도(b 값)는 조금 감소하는 경향을 나타내 다른 경향을 보였 는데, 이는 사용원료의 차이에서 오는 결과로 사료된다.

\section{요 약}

본 연구에서는 토마토 농축액을 이용한 무가당 알코올 발효를 통해 가장 우수한 균주를 선발하고자 하였다.

토마토 와인을 제조할 토마토 농축액 $\left(25^{\circ} \mathrm{Brix}\right)$ 의 수분 함량은 $67.33 \%$, 조단백질 함량은 $1.90 \%$, 조지방 함량은 $0.03 \%$, 조회분 함량은 $0.02 \%$, 가용성 무질소물은 $30.72 \%$ 로 나타났고, 유리당은 fructose, glucose가 함유되어 있었고, 유리아미노산이 총 19종으로 glutamic acid가 $814.7 \mathrm{mg} / 100$ $\mathrm{g}$ 로 가장 많이 함유되어 있었다.

알코올 함량은 발효 3 일째 가장 높은 알코올 함량을 보였 으며, 사용 균주 중 사용 균주 중 $\operatorname{TWB}(S$. cerevisiae ICVD-47)는 $8.20 \%$ 로 가장 높은 알코올 함량을 나타내었고, 당도는 발효 4일차에서도 TWB(S. cerevisiae ICVD-47)는 13.25 로 가장 낮은 잔류당 함량을 나타내었고, 각 균주의 당도는 13.25 13.45 ${ }^{\circ} \mathrm{Brix}$ 로 비슷한 경향을 나타내었다. 환 원당은 4일차에서 $28.37 \sim 28.48 \mathrm{mg} / \mathrm{mL}$ 의 값을 나타내어 알 코올 발효 균주에 따른 차이가 없는 것으로 나타났다. $\mathrm{pH}$ 는 4.31 4.55의 값을 나타내어 균주에 따른 $\mathrm{pH}$ 의 차이는 없는 것으로 나타났다. 총산은 사용된 균주 모두 1 일차에서 4 일 차까지 큰 변화가 없는 것으로 나타났다. 색도 $\mathrm{L}, \mathrm{a}$, 및 $\mathrm{b}$ 값은 사용된 균주 간에는 차이가 없는 것으로 나타났다. 이상의 결과 토마토 농축액 알코올 발효에 적합한 균주는 알코올 생성량이 높고, 낮은 잔류당 함량을 가진 $\operatorname{TWB}(S$. cerevisiae ICVD-47)가 가장 좋은 것으로 판단된다.

\section{감사의 글}

이 논문은 2013학년도 경북대학교 전임교원 연구년 교수 연구비에 의하여 연구되었음

\section{References}

1. Choi SH, Kim DH, Kim DS (2011) Comparison of ascorbic acid, Lycopene, $\beta$-carotene and a-carotene contents in processed tomato products, tomato cultivar and part. Culinary Science \& Hospitality Research, 17, 263-272

2. Lee JS, Cho MS, Hong JS (2008) Quality characteristics of Sulgidduk containing added tomato powder. Korean J Food Cook Sci, 24, 375-381

3. Seong YG (2007) Studies on the practical use of tomato processing food. Final Report of RDA, p 7-39

4. Kim HS, Chin KB (2011) Physico-chemical properties and antioxidant activity of pork patties containing various tomato powders of solubility. Korean J Food Sci Ani Resour, 31, 436-441

5. Min HS, Jin SK, Kim IS (2009) Effects of addition of hot-air dried tomato powder on the physicochemical and sensory properties of meat patties during freezing storage. J Anim Sci Technol (Kor), 51, 61-68

6. Kwon SJ, Choi JS, Yeo SH, Park HD (2015) Fermentation characteristics of persimmon wine by the mixed culture of Pichia anomala JK04 and Saccharomyces cerevisiae Fermivin cells. Korean J Food Preserv, 22, 768-777

7. Bing DJ, Kim HJ, Lee OS, Chun SS (2015) Development of rose sparkling wine with reed root extracts. Korean J Food Nutr, 28, 666-675

8. Hwang HY, Ha HT, Ha SB, Seong GU, Hwang IW, Chung SK (2015) Quality characteristics and antioxidant capacities of oriental melon wine depending on pretreatments. Korean J Food Preserv, 22, 421-427

9. Seo SH, Yoo SA, Kang BS, Son HS (2014) Quality characteristics of Korean black raspberry Bokbunja wines produced using different amounts of water in the fermentation process. Korean J Food Sci Technol, 46, 33-38

10. Seo SH, Yoo SA, Park SE, Son HS (2014) Effectiveness of yeast nutrients on stuck fermentation of blueberry wine. Korean J Food Sci Technol, 46, 143-147

11. Kim GH, Kim JH, Yang JY (2014) Change in flavor 
components of black-fermented garlic wine according to the type of chips during the manufacturing process. J Fd Hyg Safety, 29, 73-77

12. Kim KI, Kim ML (2010) Characteristics of wine fermented from mulberry juice. Korean J Food Preserv, 17, 563-570

13. Lee DH, Kang HY, Lee YS, Cho CH, Park IT, Kim HD, Lim JW (2012) Brewing and quality characteristics of Korean honey wine (Mead) with a variety of honey and yeast. Korean J Food Sci Technol, 44, 736-742

14. AOAC (1990) Official methods of analysis. 15th ed, Association of Official Analytical Chemists, Washington DC, USA, p 8-35

15. Wilson AM, Work TM, Bushway AA, Bushway RJ (1981) HPLC determination of fructose, glucose and sucrose in potatoes. J Food Sci, 46, 300-301

16. NTSTSI (2005) Manufacturing guideline of Takju and Yakju. National Tax Service Technical Service Institute. Seoul, Korea, p 195-198

17. Miller GL (1959) Use of dinitrosalicylic acid reagent for determination of reducing sugar. Anal Chem, 31, 426-428

18. AOAC (2000) Official Methods of Analysis. 17th ed, Approved methods of the Association of Official Analytical Chemisits, Washington DC, USA, p 942

19. Kim HS, Son BY, Park SM, Lee KT (1999) A study on the properties and utilization of chitosan coating: 2 . Changes in the quality of tomatoes by chitosan coating. J Korean Fish Soc, 32, 568-572

20. Kim HR, Ahn JB (2014) Analysis of free amino acids and polyphenol compounds from lycopene variety of cherry tomatoes. Culinary Science \& Hospitality Research, 20, 37-49

21. Lee HB, Yang CB, Yu TJ (1972) Studies on the chemical composition of some fruit vegetables and fruits in Korea ( I): On the free amino acid and sugar contents in tomato, watermelon, muskmelon, peach and plum. Korean J Food Sci Technol, 4, 36-43

22. Roh HI, Chang EH, Jeong ST, Jahng KY (2008) Characteristics of fermentation and wine quality. Korean J Food Preserv, 15, 317-324

23. Jang SY, Woo SM, Jo YJ, Kim OM, Kim IH, Jeong YJ (2010) Quality characteristics of tomato wine on fermentation conditions. J Korean Soc Food Sci Nutr, 39, 443-448

24. Kim EJ, Kim YH, Kim JW, Lee HH, Ko YJ, Park MH, Lee JO, Kim YS, Ha YL, Ryu CH (2007) Optimization of fermentation process and quality properties of wild grape wine. J Korean Soc Food Sci Nutr, 36, 366-370

25. Woo SM, Lee MH, Seo JH, Kim YS, Choi HD, Choi IW, Jeong YJ (2007) Quality characteristics of kiwi wine on alcohol fermentation strains. J Korean Soc Food Sci Nutr, 36, 800-806

26. Kim HR, Kwon YH, Kim HB, Ahn BH (2006) Characteristics of mulberry fruit and wine with varieties. J Korean Soc Appl Biol Chem, 49, 209-214

27. Bae IY, Lee KY, Shin MS, Lee HG (2004) Development of red wine using Monascus anka. Korean J Food Sci Technol, 36, 744-748 